\title{
Pembelajaran Matematika Di Era Pandemi COVID-19 (Studi Deskriptif pada Siswa Kelas VIII MTs. Ma'Arif 02 Kotagajah)
}

Rizka Tri Andini, Siti Annisah, Sri Wahyuni

How to cite : Andini, R. T., Annisah, S., \& Wahyuni, S. (2021). Pembelajaran Matematika Di Era Pandemi COVID-19 (Studi Deskriptif pada Siswa Kelas VIII MTs. Ma'Arif 02 Kotagajah). Kognitif: Jurnal Riset HOTS Pendidikan Matematika, 1(2), 124 - 143. https://doi.org/10.51574/kognitif.v1i2.106

To link to this article : https://doi.org/10.51574/kognitif.v1i2.106

Opened Access Article

Published Online on 1 Desember 2021

$\underline{\text { Submit your paper to this journal }}$ 


\title{
Pembelajaran Matematika Di Era Pandemi COVID-19 (Studi Deskriptif pada Siswa Kelas VIII MTs. Ma'Arif 02 Kotagajah)
}

\author{
Rizka Tri Andini $^{1 *}$, Siti Annisah ${ }^{1}$, Sri Wahyuni ${ }^{1}$ \\ ${ }^{1}$ Program Studi Tadris Matematika, IAIN Metro Lampung
}

\section{Article Info \\ Article history: \\ Received Sept 11, 2021 \\ Accepted Nov 27, 2021 \\ Published Online Dec 1, 2021}

\section{Keywords:}

Mathematics Learning COVID-19 Pandemic

Online Learning

\begin{abstract}
Sejak Maret 2020 Indonesia dihebohkan dengan Corona Virus Disease 2019 (COVID-19). Pasca pandemi, pembelajaran di Indonesia dilakukan secara online Implementasi pembelajaran online melalui media WhatsApp Group (WAG) dan video dari youtube. Dalam pelaksanaan pembelajaran online diperlukan perhatian khusus mengenai media, metode, dan cara penyampaian materi. Tujuan penelitian ini adalah untuk mendeskripsikan pembelajaran matematika di era pandemi dilakukan pada siswa kelas VIII di MTs Ma'Arif 02 Kotagajah.Jenis penelitian ini adalah deskriptif kualitatif dengan pendekatan fenomenologis, yaitu mengamati fenomena atau peristiwa pembelajaran matematika yang diberikan kepada siswa kelas VIII MTs Ma'Arif 02 Kotagajah di era pandemi. Teknik pengumpulan data dalam penelitian ini menggunakan wawancara dan dokumentasi dengan responden yang digunakan adalah guru dan siswa. Teknik keabsahan data penelitian adalah triangulasi sumber, kemudian untuk teknik analisis data menggunakan model Miles dan Huberman dengan tahapan reduksi data, penyajian data, dan penarikan kesimpulan.Hasil yang ditemukan adalah pembelajaran matematika pada siswa kelas VIII di MTs. Ma'Arif 02 Kotagajah berjalan dengan baik sesuai dengan persiapan yang dilakukan guru, namun terjadi penurunan hasil belajar siswa karena siswa kesulitan memahami materi matematika secara online, padahal guru sudah menjelaskan jawaban secara tatap muka selama satu jam di kelas dengan mematuhi protokol kesehatan. Metode pembelajaran online yang digunakan guru adalah metode ceramah dan tanya jawab, sedangkan media pembelajaran online menggunakan WAG dan video dari youtube.
\end{abstract}

This is an open access under the CC-BY-SA licence

All rights reserved.

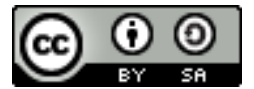

\section{Corresponding Author:}

Riska Tri Andini,

Tadris Matematika,

Fakultas Tarbiyah dan Ilmu Keguruan,

IAIN Metro Lampung,

J1. Ki Hajar Dewantara Kampus 15A Iringmulyo Metro Timur, Kota Metro, Lampung, 34112, Indonesia

Email: rizkatriandini1211@gmail.com 


\section{Pendahuluan}

Matematika merupakan ilmu pengetahuan universal yang berguna untuk kehidupan manusia dan menjadi ilmu dasar perkembangan teknologi modern. Dengan demikian diperlukan penguasaan matematika yang kuat, agar siswa memiliki bekal kemampuanberpikir logis, kritis, dan kreatif. Berdasarkan Kurikulum 2013, tujuan dari pembelajaran matematika untuk menekankan siswa dalam kemampuan observasi, bertanya, mencoba atau eksperimen, bernalar, menyajikan, dan mengkomunikasikan apa yang diperoleh dan mencipta (Syahlan, $\underline{2013}$ ). Oleh sebab itu penguasaan materi matematika dapat dijadikan solusi untuk mewujudkan terciptanya masyarakat belajar (learning society), sehingga masyarakat memiliki hak mendapatkan pendidikan dan memiliki peran sebagai pembelajar seumur hidup.

Peran matematika sangat penting dimiliki siswa untuk menghadapi perkembangan iptek yang terus berkembang. Pada hakikatnya matematika sebagai suatu kegiatan pengetahuan yang mengembangkan sikap berpikir kritis, objektif, terbuka, dan pengetahuan yang terstuktur (Pujiadi, 2016). Dengan demikian matematika yang dipejalari di sekolah adalah materi yang dipilih agar mudah diimplementasikan kegunaannya dalam kehidupan sehari-hari. Sehingga pembelajaran matematika yang dilakukan dengan pendekatan kontekstual diharapkan membantu siswa memiliki kompetensi pengetahuan, sikap, dan keterampilan yang lebih baik.

Hakikat pembelajaran yang ideal bukan berarti hasil belajar siswa yang benar dengan sempurna. Pembelajaran yang ideal adalah proses pembelajaran yang tidak hanya terfokus pada hasil yang dicapai siswa, tetapi tentang bagaimana pelaksanaan pembelajaran dapat memberikan pemahaman yang baik, ketekunan, kecerdasan, mutu, dan perubahan perilaku siswa menjadi lebih baik dengan menerapkannya dikehidupan sehari-hari. Untuk tercapainya tujuan proses pembelajaran matematika yang bermutu maka guru hendaknya mengupayakan siswa untuk mengerti dan memahami materi pembelajaran. Sehingga guru tidak hanya berpatokan pada target kurikulum, tetapi juga memperhatikan pemahaman siswa pada saat proses pembelajaran dan hasil akhir.

Berbagai model dan metode pembelajaran matematika yang digunakan di sekolah memiliki kelebihan dan kekurangannya masing-masing. Namun hal tersebut mendadak berubah dengan segala yang berkaitan dengan jaringan internet, era digital, hingga perkara kesehatan yang terkait social distancing dan phisycal distancing. Mulai Maret 2020 Indonesia sudah digemparkan Corona Virus Disease 2019 (COVID-19), yang cepat menyebar hingga ke seluruh wilayah Indonesia. Dampak yang luar biasa dari Pandemi COVID-19 baik ditingkat nasional hingga internasional. Bidang di Indonesia yang tidak kalah penting mendapatkan dampak pandemi tersebut adalah bidang pendidikan.

Sejak adanya pandemi COVID-19 pembelajaran dilakukan secara dalam jaringan (daring), meskipun demikian tujuan dari pembelajaran matematika harus tetap tercapai. Pelaksanaan pembelajaran menggunakan media, metode, dan bahan ajar yang serba online. Contoh dari media belajar online seperti Google Clasroom, Google Meet, WhatsApp Group, youtube. Seperti yang dilakukan di MTs Al-Hidayah Purwokerto Utara, pembelajaran matematika dilaksanakan secara daring menggunakan WhatsApp dan Zoom meet. Namun adanya kendala yang dialami yaitu lemahnya sinyal internet, kuota internet, dan sulitnya siswa untuk memahami materi (Naila, 2021). Selain itu di SMP Nurul Ikhlas menggunakan aplikasi Google Clasroom, Google Meet, WhatsApp Group, dan Zoom Meeting. Untuk media yang digunakan alat-alat yang ada di rumah siswa masing-masing. Namun adanya kendala infrastrktur pendukung kegiatan pembelajaran dan kuota internet (Handayani \& Irawan, 2020).

Berdasarkan hasil wawancara dengan guru matematika di MTs.Ma'Arif 02 Kotagajah, diketahui bahwa semenjak tanggal 16 Maret 2020 pembelajaran di sekolah yang semulanya dilakukan tatap muka sementara dilaksanakan di rumah masing-masing, kegiatan pembelajaran 
didampingi orang tua atau keluarga. Pelaksanaan ini berdasarkan Surat Edaran Kementerian Pendidkan dan Kebudayaan Republik Indonesia Nomor 4 Tahun 2020 terkait anjuran pembelajaran, yang semula dilakukan tatap muka di sekolah menjadi pembelajaran dari rumah atau daring untuk mencegah penyebaran COVID-19 (Surat Edaran Kemendikbud, 2020). Kemudian guru matematika menerangkan bahwa pembelajaran daring yang dilakukan dengan cara menyampaikan materi melalui via grupWhatsapp dan video dari youtube. Karena metode yang dilakukan tidak tatap muka maka proses pembelajaran kurang efektif dan kondusif, selain itu sulitnya jangkauan guru untuk memperhatikan kegiatan siswa dalam jam pelajaran karena hanya terhubung melalui grup Whatsapp. Selain pembelajaran daring di MTs. Ma'Arif 02 Kotagajah juga melaksanakan pembelajaran matematika secara luring atau tatap muka. Pembelajaran matematika secara tatap muka dilaksanakan satu minggu sekali selama satu jam. Pembelajaran dilaksanakan dengan menerapkan protokol kesehatan, dengan pembagian jadwal yang berbeda antara kelas VII-IX.

Untuk memperoleh hasil pembelajaran yang baik tidak hanya dari metode atau model pembelajaran yang digunakan guru, tetapi juga partisipasi dan pemahaman siswa terhadap materi matematika juga diperhatikan. Terlebih di era pandemi COVID-19 yang sedang melanda seluruh dunia dengan dampak yang dirasakan mulai dari pertahanan negara, perekonomian pengusaha besar hingga masyarakat menengah ke bawah, serta dibidang pendidikan. Dalam dunia pendidikan, pelajaran matematika merupakan pelajaran yang memiliki peran penting dalam kehidupan sehari-hari, meskipun tidak semua masalah kehidupan sehari-hari merupakan permasalahan matematis (Sholihah \& Mahmudi, 2015).

Pembelajaran matematika yang kini dilaksanakan dengan daring tentunya membuat guru harus lebih kreatif dalam memilih teknis pembelajaran. Pembelajaran di era pandemi COVID-19 masih menjadi pertanyaan terkait langkah-langkah proses pembelajaran, serta ketercapaian pembelajaran terhadap siswa. Sebab pembelajaran daring hendaknya tetap mengutamakan proses belajar siswa untuk menuju hasil. Sehingga siswa tidak hanya sekedar mengerjakan lalu diberi nilai, tetapi guru juga memberi kesan belajar yang lebih bermakna. Oleh sebab itu, penelitian ini bertujuan untuk mendeskripsikan pembelajaran matematika di era pandemi COVID-19 yang khususnya dilaksanakan di MTs. Ma'Arif 02 Kotagajah.

Penelitian ini penting dilakukan saat ini yaitu pada era pandemi COVID-19, karena dapat memberikan informasi kepada pembaca untuk mengetahui kekurangan dan kelebihan belajar daring, kendala-kendala yang dialami siswa maupun guru, serta metode dan media yang digunakan dalam pelaksanaan pembelajaran matematika secara daring. Selain itu, penelitian ini penting karena dapat dijadikan sebagai bahan bahan evaluasi guru untuk merancang proses pembelajaran matematika yang lebih baik lagi kedepannya.

\section{Metode}

Penelitian ini merupakan penelitian kualitatif dengan metode deskriptif. Metode penelitian deskriptif kualitatif mempunyai tujuan untuk mendeskripsikan suatu aktivitas atau fenomena yang diteliti. Dalam penelitian ini mendeskripsikan aktivitas pembelajaran matematika di era pandemi COVID-19 khususnya yang diberikan pada siswa kelas VIII di MTs Ma'Arif 02 Kotagajah. Penelitian ini menggunakan pendekatan fenomenologi yang mengamati fenomena atau kejadian pembelajaran matematika yang dilakukan di MTs Ma'Arif 02 Kotagajah di era pandemi.

Sumber data yang digunakan yaitu sumber data primer dan sumber data sekunder. Sumber data primer berupa wawancara dengan responden guru matematika siswa. Wawancara 
yang diberikan tekait proses pembelajaran yang dimulai dari persiapan hingga evaluasi. Teknik pengambilan sampel penelitian ini menggunakan purposive sampling, karena penentuan sampel dengan tujuan dan pertimbangan tertentu (Sugiyono, 2010). Pengambilan sampel berdasarkan rekomendasi dari guru matematika, karena keadaan siswa yang bersifat heterogen pada setiap kelas. Sehingga narasumber sebanyak 20 siswa yang terdiri dari 5 kelas, dengan setiap kelasya diambil sebanyak 4 siswa. Sumber data sekunder dalam penelitian ini bertujuan untuk mendukung proses analisis data. Dokumentasi yang digunakan berupa Rencana Pelaksanaan Pembelajaran (RPP) yang dibuat oleh guru matematika, alat evaluasi belajar seperti soal berbentuk pilihan ganda maupun soal essay, dan hasil belajar siswa.

Berikut kisi-kisi pedoman wawacara untuk guru mata pelajaran matematika dan siswa:

Tabel 1. Kisi-Kisi Pedoman. Wawancara untuk. Mendapatkan Data Pembelajaran Guru Selama Belajar Daring

\begin{tabular}{lllc}
\hline No. & $\begin{array}{c}\text { Tahapan } \\
\text { Pembelajaran }\end{array}$ & \multicolumn{1}{c}{ Indika tor } & $\begin{array}{c}\text { Butir } \\
\text { Pertanyaan }\end{array}$ \\
\hline 1. & $\begin{array}{l}\text { Pendahuluan atau } \\
\text { Persiapan }\end{array}$ & Persiapan pe mbelajaran daring oleh guru & $1,2,3$ \\
\hline 2. & Pelaksanaan & a. Cara penyampaian materi pembelajaran & 4,5 \\
& & b. Metode atau model yang digunakan guru & $6,7,8$ \\
& & c. Kendala guru dalam mempersiapkan pembelajaran daring & 9,10 \\
& & d. Cara guru menggunakan media pembelajaran & 11,12 \\
\hline 3. & Penutup atau & Tingkat keberhasilan metode atau model yang digunakan & $13,14,15$ \\
& Evaluasi & & \\
\hline
\end{tabular}

Tabel 2. Kisi-Kisi Pedoman Wawancara untuk Mendapatkan Data Pembelajaran Siswa

\begin{tabular}{|c|c|c|c|}
\hline \multicolumn{4}{|c|}{ Selama Daring } \\
\hline No. & $\begin{array}{c}\text { Tahapan } \\
\text { Pembelajaran }\end{array}$ & Indika tor & $\begin{array}{c}\text { Butir } \\
\text { Pertanyaan }\end{array}$ \\
\hline 1. & $\begin{array}{l}\text { Pendahuluan atau } \\
\text { Persiapan }\end{array}$ & Pesiapan mengikuti pembelajaran & $1,2,3$ \\
\hline 2. & Pelaksanaan & $\begin{array}{l}\text { a. Pendapat siswa terkait penyampaian guru } \\
\text { b. Jenis metode atau model yang digunakan guru } \\
\text { c. Kendala siswa dalam menyelesaikan tugas dan ulangan } \\
\text { d. Kekreatifan guru dalam menggunakan media pembelajaran }\end{array}$ & $\begin{array}{c}4,5 \\
6,7,8 \\
9,10 \\
11,12\end{array}$ \\
\hline 3. & $\begin{array}{l}\text { Penutup atau } \\
\text { Evaluasi }\end{array}$ & Tingkat pemahaman siswa dalam belajar & $13,14,15$ \\
\hline
\end{tabular}

Instrumen pedoman wawancara sebelum diberikan kepada sumber data akan diuji validitas isinya. Uji validitas isi penelitian ini menggunakan expert judgement koefesien validitas Aiken's V dengan tiga ahli. Uji validitas isi ini digunakan untuk melihat validitas tiap aitem pada kisi-kisi, sehingga pertanyaan yang berikan pada saat wawancara relevan dengan indikator pelaksanaan pembelajaran. Setiap aitem yang dinilai dilakukan dengan cara skala Likert memberikan nilai 1(tidak sesuai) sampai dengan 5 (sangat sesuai). Berikut rumus validitas Aiken's V:

$$
V=\frac{\sum s}{[n(c-1)]}
$$

Keterangan:

$V=$ Indeks kesepakatan ahli/rater mengenai validitas butir

$s=$ Skor yang diberikan setiap ahli/rater dikurangi skor terendah/minimak dalam kategori yang dipakai

$n=$ Banyaknya ahli/rater 
$c=$ Skor tertinggi/maksimal dalam kategori yang dapat dipilih ahli/rater

Kriteria Nilai V:

\begin{tabular}{cc}
\hline Nilai Indeks $\boldsymbol{V}$ & Kriteria \\
\hline$V<0,4$ & Kurang Valid \\
\hline $0,4 \leq V \leq 0,8$ & Valid \\
\hline$V>0,8$ & Sangat Valid \\
\hline
\end{tabular}

Teknik keabsahan data pada penelitian ini menggunakan triangulasi sumber. Triangulasi sumber bertujuan untuk menguji kredibilitas data, dengan cara mewawancarai guru dan siswa kemudian melakukan pengecekan pada dokumentasi penelitian dari guru terkait persiapan, teknis, dan hasil belajar siswa. Jika hasil uji penelitian wawancara antara guru dan siswa tidak sama dengan dokumentasi, maka uji akan terus dilakukan sampai data penelitian ditemukan kepastiannya.

Teknik analisis data penelitian ini berdasarkan model Miles and Huberman, yaitu penelitian akan terus dilakukan hingga data tuntas atau sampai data yang diperoleh jenuh. Tahap analisis data model Miles and Huberman memiliki tiga tahap analisis; (1) Tahap reduksi data (data reduction), Tujuan dilakukan reduksi data jika hasil data dari triangulasi dilakukan beberapa kali, sehingga mempermudah dalam penarikan kesimpulan. (2) Tahap kedua yaitu penyajian data (data display), data pada penelitian ini disajikan dengan bentuk uraian yang bersifat deskriptif. Data yang dideskripsikan terkait hasil wawancara dan dokumentasi yang telah dilakukan. (3) Tahap ketiga yaitu penarikan kesimpulan (conclusing drawing), kesimpulan yang akan didapatkan mengenai pembelajaran matematika di era pandemi COVID19. Hasilnya terkait proses pelaksanaan pembelajaran yang diterapkan guru berdasarkan metode atau model pembelajaran, RPP, media pembelajaran, evaluasi pembelajaran mengenai hasil belajar siswa, kendala siswa dalam penyelesaian soal matematika, dan lain-lain yang berhubungan dengan proses pembelajaran.

\section{Hasil Penelitian}

Hasil pada penelitian ini sesuai dengan tahapan pembelajaran, yaitu persiapan atau pendahuluan, pelaksanaaan, dan evaluasi pembelajaran

a. Persiapan Pembelajaran

Untuk persiapan pembelajaran matematika di MTs. Ma'Arif 02 Kotagajah selama pandemi dilakukan secara daring, sehingga persiapan guru matematika harus sejalan dengan peraturan pemerintah. Menurut guru matematika kelas VIII persiapan awal yang dilakukan dengan membuat RPP belajar daring. Kemudian untuk bahan ajar yang digunakan disesuaikan dengan media belajar secara daring. Berikut hasil wawancara dengan bapak Tamimi selaku guru matematika terkait persiapan yang dilakukan sebelum proses pembelajaran:

"Persiapan saya sebelum mengajar membuat RPP, bahan ajar, dan soal latihan yang akan diberikan pada siswa. Untuk RPP yang saya buat sesuai dengan format RPP daring sedangkan untuk bahan ajarnya saya sesuaikan dengan kelas, karena kelas VIII A hingga VIII E memiliki kemampuan dalam memahami materi yang berbeda." 
Kemudian bapak Tamimi menjelaskan lebih rinci mengenai bahan ajar yang dibuat untuk kelas VIII A hingga VIII E.

“...Seperti contohnya kelas A memiliki pemahaman yang lebih jadi saya buat melalui WhatsApp Group (WAG) dan materinya melalui video, tetapi untuk kelas VIII D saya berikan materi melalui pdf dan juga video agar mereka lebih mudah memahami materi. Kemudian untuk evaluasi pembelajarannya saya membuat ulangan tengah semester dan ulangan akhir semester seperti pada sekolah lain pada umumnya."

Pertanyaan dengan bapak Tamimi berikutnya terkait kesesuaian antara persiapan yang dilakukan dengan pedoman kurikulum dan Kemendikbud: "Saya usahakan seperti itu. Meskipun madrasah ini swasta tetapi harus mengikuti aturan pemerintah, seperti anjuran untuk belajar daring atau belajar dari rumah dan mengikuti pedoman menggunakan media belajar daring."

Selain guru matematika, wawancara juga dilakukan dengan siswa kelas VIII A hingga VIII E. Mewawancarai siswa bertujuan untuk mengetahui bagaimana persiapan siswa sebelum memulai pembelajaran. Wawancara dilakukan dengan Nayla Nur Apriyani yang merupakan siswa kelas VIII A mengenai persiapan mengikuti pembelajaran matematika: "Persiapan belajar lebih mudah untuk memulai pelajaran, tidak perlu terburu-buru untuk datang ke sekolah. Tetapi saya tidak belajar telebih dahulu, biasanya saya mempersiapkan buku dan alat tulis agar bisa langsung mencatat dan memahami materi." Kemudahan persiapan belajar daring juga dirasakan oleh Nisa Hardiyanti siswa kelas VIII B: "Persiapan saya berbeda dari belajar tatap muka, untuk alat tulis dan buku bisa dengan mudah saya siapkan dari rumah. Untuk belajar daring mempermudah saya karena tidak perlu membawa buku banyak ke sekolah."

Meskipun Saskia Diah Larasati belajar di kelas VIII D, namun semangatnya untuk mempersiapkan belajar daring juga baik: "Saya mempersiapkan materi yang akan dipelajari selanjutnya, karena saya memiliki pdf buku matematika jadi tahu materi kelanjutan, kalau alat tulis dan buku tulis pasti saya siapkan juga." Di samping adanya siswa yang sungguh-sungguh dan semangat dalam mempersiapkan pembelajaran, siswa kelas VIII juga ada yang hanya sekadarnya saja dalam persiapan mengikuti pembelajaran. Seperti yang diungkapkan oleh Eva Anisa dari kelas VIII C: "Saya mempersiapkan alat tulis, buku, dan kertas folio. Karena untuk tugas yang diberikan guru dikerjakan di kertas folio dan dikumpulkan ke sekolah seminggu sekali."

b. Pelaksaan Pembelajaran

1) Cara Penyampaian Materi Pembelajaran

Berdasarkan hasil wawancara dengan bapak Tamimi terkait kelanjutan dari pertanyaan persiapan pembelajaran, yaitu kesesuaian pelaksanaan dengan RPP yang dibuat oleh guru:

"Pelaksanaan pembelajaran dengan RPP yang saya buat sudah sesuai, saya membuat RPP yang sederhana agar mempermudah siswa juga untuk mengikuti pembelajaran. Langkah awalnya saya memulai pembelajaran dengan mengucap salam dan menyapa siswa di WhatsApp Group (WAG) kemudian memberikan penjelasan materi dan selanjutnya memberikan soal pada siswa, dan tekadang saya membuka sesi tanya jawab kemudian menutup pembelajaran."

Jawaban dari bapak Tamimi sejalan dengan jawaban dari siswa kelas VIII. Siswa kelas VIII A yang bernama Muhammad Yusuf, yaitu: "Guru menyampaikan materi dengan berceramah tetapi melalui WAG jadi penjelasannya terbatas. Tetapi semenjak pertengahan 
semester kemarin setiap mengumpulkan tugas seminggu sekali setiap guru menjelaskan di depan kelas." Untuk pembelajaran di kelas VIII A ditambahkan oleh Intan Anisa Putri bahwa: "Caranya guru menjelaskan materi melalu WAG atau beberapa kali terakhir ini menggunakan GoogleMeet kemudian memberikan soal yang dikumpulnya seminggu sekali." Namun berbeda dengan kelas VIII D oleh Muhammad Dwi Lutfi, bahwa: "Guru sering membagikan link video dari youtube dan tidak menjelaskan materinya lagi di WAG kemudian memberikan soal latihan yang dikumpul seminggu sekali ke sekolah."

2) Metode atau Model Pembelajaran

Berdasarkan wawancara yang dilakukan dengan bapak Tamimi terkait metode atau model yang digunakan, maka berikut hasil wawancaranya: "Saya menggunakan metode ceramah dan tanya jawab melalui WAG. Karena menurut saya matematika merupakan pelajaran yang sukar sehingga harus tetap diberikan penjelasan dari guru, karena keadaan serba online metode ceramah yang saya lakukan melalui daring tidak serinci seperti belajar tatap muka." Kemudian wawancara dilanjutkan tentang metode yang digunakan setiap pembelajaran matematika: "Terkadang saya menggunakan metode ceramah, metode tanya jawab, terkadang keduanya, tapi kalau dari video youtube saya tidak menggunakan metode." Kesesuaian metode juga bapak Tamimi jelaskan saat diwawancarai: "Menurut saya metode yang saya gunakan sudah sesuai, karena untuk khususnya pelajaran matematika harus dijelaskan terlebih dahulu oleh guru. Sehingga cara ini menggunakan metode ceramah untuk mendukung tujuan tersebut meskipun melalui belajar daring di era pandemi."

Selain wawancara dengan guru, mewawancarai juga diberikan pada siswa terkait kesesuian dan macam metode atau model yang digunakan guru. Berdasarkan hasil wawancara dengan siswa kelas VIII A yaitu Dwi Apriliasari bahwa: "Guru terkadang menggunakan metode ceramah dalam pembelajaran daring, yaitu dengan menjelaskan materi terlebih dahulu sebelum memberikan soal untuk dikerjakan. Menurut saya metode ini sudah cukup sesuai tapi ada dimateri tertentu menjadi belajar dari sumber lain juga." Menurut Dika Prasetyo siswa kelas VIII C bahwa: "Guru menggunakan metode ceramah dalam WAG dan sesekali diadakan sesi tanya jawab dengan siswa. Guru tidak selalu menggunakan metode yang sama, terkadang menggunakan metode ceramah jika materinya dalam bentuk foto atau pdf, tetapi jika materi yang diberikan dari youtube guru tidak menjelaskan. Dan menurut saya belum sesuai, karena terkadang materi matematika yang sulit hanya diberikan link video sedangkan yang mudah dijelaskan di WAG." Berdasarkan wawancara dengan Afrizal Afif Nurkholis siswa kelas VIII B:

\footnotetext{
"Guru menjelaskan materi di WAG tetapi itu jika materi dibagikan dalam bentuk foto. Guru menggunakan metode yang sama, hanya menjelaskan jika materi berbentuk foto dan tidak menjelaskan jika materi di youtube. Dan saya merasa sulit untuk memahami materi matematika yang diajarkan oleh guru." Pernyataan yang hampir sama disampaikan oleh Dimas Nur dari kelas VIII B: "Metode yang digunakan guru dengan berceramah jika materinya dalam bentuk foto, tetapi jika video dari youtube tidak dijelaskan. Tetapi waktu belajar daring di kelas VII hanya belajar dari youtube saja."
}

3) Kendala yang Dialami pada Pembelajaran Daring 
Berdasarkan hasil wawancara yang dilakukan dengan guru matematika MTs. Ma'Arif 02 Kotagajah, kendala yang dialami oleh bapak Tamimi sebagai berikut:

\begin{abstract}
"Kendala yang saya alami yaitu kurang referensi dalam penggunaan metode belajar agar siswa tidak merasa bosan. Pemilihan metode belajar harus saya pertimbangkan dengan kemampuan belajar siswa di MTs. Ma'Arif 02 Kotagajah juga. Sedangkan untuk penggunaan media belajar selain WAG dan youtube akan berdampak pada kuota internet juga. Kendala selanjutnya yaitu saya kesulitan untuk mengoreksi tugas yang dikirimkan melalui WA."
\end{abstract}

Kemudian untuk solusi dari kendala tersebut:

"Sudah saya bicarakan dengan pihak sekolah. Untuk solusinya pengumpulan tugas satu minggu sekali yaitu pada hari Rabu dan Kamis untuk kelas VIII, pada kedua hari tersebut saya menjelaskan langsung pada siswa terkait tugas sebelumnya yang telah siswa kerjakan. Sehingga harapan saya siswa mampu memahami materi dan saya lebih mudah mengoreksi hasil tugas siswa berbentuk kertas."

Berdasarkan wawancara yang telah dilakukan dengan siswa kelas VIII terkait kendala yang dialami dan solusi yang diberikan, maka berikut ini hasil wawancara dengan salah satu siswa kelas VIII A yang bernama Intan Anisa Putri:
"Kendalanya harus beberapa kali memahami ulang materi yang dijelaskan dan memahami sendiri di rumah, namun terkadang dibantu orang tua atau kakak. Selain itu kendala saya waktu untuk mengumpulkan tugas yang singkat. Dan untuk solusi mengumpulkan hanya melalui WAG tetapi sekarang tugas dikumpulkan langsung seminggu sekali ke sekolah, jadi ada waktu beberapa hari untuk mengerjakannya. Saat mengumpulkan tugas tersebut guru memberikan penjelasan langsung pada siswa."

Berdasarkan wawancara dengan Muhammad Yusuf dari kelas VIII A: "Kendala saya pada kuota internet, karena harus membuka youtube dan kalau belum paham berulang kali menontonnya. Video di youtube juga tidak semua bisa ditonton offline. Selama belajar daring hanya satu kali diberi kuota dari sekolah." Berdasarkan wawancara dengan Glendy Bagas Irfansyah siswa dari kelas VIII C: "Kendala saya sulit untuk memahami materi matematika tanpa ada bimbingan dari orang lain. Untuk solusi menurut saya sudah, dengan setiap minggunya siswa mengumpulkan tugas ke sekolah kemudian guru menyampaikan materi sebelumnya secara langsung di depan kelas."

Kemudian hasil wawancara dengan Muhammad Dwi Lutfi dari kelas VIII D: "Kendala saya tidak bisa selalu berkonsentrasi jika belajar daring sehingga materi yang disampaikan sulit untuk saya pahami. Kendala ini sudah saya ceritakan pada guru matematika dan solusi dari beliau untuk belajar lebih giat lagi dan jaga semangat belajar." Dan hasil wawancara dengan Fitra Ramadhani salah satu siswa kelas VIII E: "Kendala yang saya alami tidak bisa cepat dalam memahami materi matematika, belum sempat saya pahami lagi sudah menyusul pelajaran berikut yang secara daring juga. Saya pernah berkonsultasi dengan guru matematika dan beliau menjawab untuk lebih rajin membaca dan memahami materi."

4) Cara Menggunakan Media Pembelajaran 
Media pembelajaran penting digunakan untuk proses pelaksanaan pembelajaran daring, karena dengan media inilah interaksi antara guru dan siswa dapat dijalankan. Media yang digunakan untuk mendukung kegiatan belajar daring tentu saja membutuhkan laptop atau handphone, dan juga koneksi internet.

Berdasarkan wawancara yang dilakukan dengan bapak Tamimi bahwa:

"Media yang saya gunakan WAG dan youtube, namun beberapa waktu lalu saya coba menggunakan GoogleMeet di kelas VIII A. Menurut saya WAG dan youtube cukup sesuai, karena media ini saya sesuaikan dengan kendala sinyal, kuota, dan semangat siswa untuk mengikuti pelajaran. Karena jika proses pembelajaran sudah membuat siswa kesulitan maka akan repot jika ditambah dengan kesulitan memahami materi. Walaupun pastinya tetap saja tidak semua siswa kelas VIII paham dan tidak semua materi cukup dijelaskan hanya melalui WAG."

Kemudian bapak Tamimi menjelaskan tentang cara menggunakan media tersebut:

"Langkah awalnya saya membuka pembelajaran dengan mengucap salam di WAG, kemudian saya memberikan materi dalam bentuk pdf, link video youtube, dan terkadang materi dalam bentuk foto, namun jenis bentuk materi ini saya gunakan pada kelas yang berbeda-beda sesuai dengan cara belajar siswa disetiap kelas. Jika materi sudah tersampaikan saya memberi sesi pertanyaan pada siswa untuk bertanya namun mereka sulit untuk bertanya, atau mungkin mereka bingung apa yang ingin ditanyakan. Dan terakhir saya menutup pembelajaran dengan memberikan soal latihan serta mengucap salam penutup."

Berikut hasil wawancara dengan siswa, yaitu Muhammad Yusuf kelas VIII A:

"Media belajar menggunakan WAG dan youtube, kemarin sudah coba menggunakan GoogleMeet. Menurut saya sudah sesuai tetapi perlu membaca ulang agar paham. Untuk langkahnya guru memulai belajar dengan mengucap salam kadang juga menyapa siswa, kemudian guru memberikan materi dari youtube yang dibagikan linknya, kalau materi hanya berbentuk pdf guru menjelaskan tetapi jika dari youtube tidak, selanjutnya guru membagikan soal dan menutup pelajaran."

Berdasarkan hasil wawancara dengan Nisa Hardiyanti siswa kelas VIII B:

"Guru menggunakan media video youtube dan WAG, menurut saya sudah sesuai tetapi kalau ditambah sebulan sekali dengan media GoogleMeet atau ZoomMeet akan lebih baik lagi. Dan untuk langkahnya guru membuka pembelajaran dengan mengucap salam lalu guru membagikan link video youtube atau menjelaskan materi dari foto, kemudian guru membagikan soal latihan dan menutup pelajaran."

Sedangkan untuk hasil wawancara dengan Fikri Ramadan siswa kelas VIII E: 
"Kalau untuk di kelas saya menggunakan youtube dengan membagikan link video dan WAG, menurut saya media tersebut sudah sesuai. Untuk langkahnya guru mengucap salam pembuka dan siswa mengirimkan nama masing-masing sebagai absen, jika waktu absen sudah habis guru melanjutkan dengan memberi link video youtube atau materi pdf beserta soal latihan, kemudian guru mempersilakan siswa untuk bertanya setelah selesai guru menutup pembelajaran."

c. Evaluasi Pembelajaran

Berdasarkan hasil wawancara dengan bapak Tamimi selaku guru matematika kelas VIII di MTs. Ma'Arif 02 Kotagajah terkait evaluasi proses pembelajaran daring. Berikut pernyataan bapak Tamimi untuk model atau metode yang digunakan: "Belum sepenuhnya berhasil, karena pada kenyataannya siswa memang sulit untuk memahami materi. Tapi saya rasa dengan keadaan seperti ini siswa belajar lebih mandiri dan tetap menjaga semangat serta kesehatan di tengah pandemi."

Kemudian pernyataan dilanjutkan oleh bapak Tamimi untuk hasil belajar siswa selama pembelajaran daring: "Tentu saja hasil belajar siswa menurun karena kurang pahamnya materi yang diberikan, oleh sebab itu saya mencoba untuk menggunakan GoogleMeet yang baru saya coba di kelas VIII A." Berikut rekapitulasi nilai ulangan akhir semester kelas VIII sebelum dan sesudah belajar daring di era pandemi COVID-19.

Tabel 4.4. Rekapitulasi Hasil Belajar Siswa Sebelum dan Setelah Belajar Daring

\begin{tabular}{cccc}
\hline No. & Kelas & $\begin{array}{c}\text { Rata-Rata Nilai Ulangan Akhir Semester } \\
\text { Sebelum }\end{array}$ & \begin{tabular}{c} 
Setelah \\
\hline 1.
\end{tabular} \\
\hline 2. & VIII A & 87,0 & 75,3 \\
\hline 3. & VIII B & 86,0 & 75,0 \\
\hline 4. & VIII C & 84,2 & 75,1 \\
\hline 5. & VIII D & 82,5 & 73,7 \\
\hline
\end{tabular}

Selanjutnya hasil wawancara terkait saran atau solusi untuk guru matematika dalam penyampaian materi matematika: "Saran saya menggunakan model atau metode pembelajaran disesuaikan dengan keadaan siswa, memang banyak metode dan media belajar daring yang canggih namun tujuan dari belajar yang utama adalah siswa mampu memahami pelajaran bukan hanya sekedar mampu mengikuti trend media belajar daring."

Berdasarkan hasil wawancara dengan siswa tentang pemahaman materi dan saran untuk guru matematika agar lebih baik lagi kedepannya. Berikut pernyataan dari Nayla Nur Apriyanti dari kelas VIII A: "Tidak semua materi matematika saya pahami, pembelajaran daring malah mempersulit untuk menguasai pelajaran matematika. Saran saya sebaiknya guru matematika memberikan perhatian lebih pada siswa yang kesulitan untuk memahami materi, dan memberikan pertanyaan pada siswa tentang cara penyampaian materi seperti apa yang diinginkan agar kedepannya lebih baik lagi."

Namun ada perbedaan dengan Intan Anisa Putri yang sama-sama belajar di kelas VIII A: "Alhamdulillah paham, meskipun ada materi sulit yang masih bingung. Kalau saya lebih suka belajar tatap muka, namun keadaan pandemi seperti ini belajar daring tidak masalah karena untuk kesehatan kita juga. Dan sarannya untuk guru matematika memberikan video yang dibuat oleh guru langsung atau memberikan sesi pertanyaan lebih banyak agar siswa yang lain bisa bertanya lebih rinci."

Berdasarkan hasil wawancara dengan Syifa Annisatun Nabilla dari kelas VIII C: "Saya tidak paham, tapi semenjak guru menjelaskan materi saat pengumpulan tugas saya merasa ada 
kemajuan untuk memahami materi, karena setelah itu saya bisa bertanya pada teman juga. Pembelajaran daring tidak mempermudah, tapi karena di era pandemi tetap saya ikuti cara belajar yang sudah ditetapkan dari sekolah. Saran saya untuk waktu membahas atau menjelaskan materi matematika di sekolah yang dilakukan seminggu sekali ditambahkan waktunya, terutama untuk pelajaran matematika."

Berdasarkan hasil wawancara dengan Saskia Diah Larasati dari kelas VIII D: "Saya tidak langsung paham, jadi harus membaca atau memahami ulang. Pembelajaran daring tidak mempermudah, tetapi jika dipahami lagi insyaAllah saya bisa memahami. Saran saya untuk guru matematika memberikan penjelasan dengan metode ceramah dan tanya jawab meskipun dari video youtube. Selain itu untuk penjelasan materi bisa dengan cerita sehari-hari atau dihubungkan dengan kehidupan nyata."

Berdasarkan hasil wawancara dengan Fikri Ramadan siswa kelas VIII E: "Paham tetapi tidak dengan sekali memahami, dan pastinya ada materi yang tidak saya pahami hingga kini. Pembelajaran ini tidak mempermudah, karena perlu ketekunan dan sabar yang lebih dibandingkan belajar tatap muka. Saran untuk guru matematika semoga bisa menggunakan cara-cara menarik lainnya agar siswa lebih semangat untuk belajar, dan sering memberikan cara-cara mudah dalam penyelesai soal juga."

Saran untuk guru matematika selanjutnya dari Fitra Ramadhani siswa kelas VIII E: "Saran saya untuk sekolah dan guru matematika waktu untuk penjelasan matematika di sekolah saat pengumpulan tugas ditambah lagi, dan memberikan motivasi saat belajar daring."kemudian wawancara dengan Siti Fatimah siswa kelas VIII E: "Tidak semua materi matematika selama daring dapat saya pahami, hanya beberapa materi saja. Belajar daring tidak mempermudah, namun saya tetap mendukung pembelajaran ini agar mencegah penularan COVID-19 dan semoga segera bisa dilanjutkan dengan sekolah tatap muka. Saran saya guru hanya beberapa materi saja penyampaiannya dari video youtube atau bisa diganti dengan video yang dibuat oleh guru matematika sendiri, agar bahasa yang digunakan juga bahasa biasa yang digunakan saat di kelas."

\section{Diskusi}

\section{a. Persiapan Pembelajaran}

Berdasarkan hasil wawancara dengan bapak Tamimi, bahwa bapak Tamimi telah menyesuaikan persiapan pembelajaran dengan panduan dari Kemendikbud seperti pembuatan RPP belajar daring. Pernyataan tersebut telah disesuaikan dengan bentuk fisik dari RPP yang dibuat guru, untuk langkah yang ada dalam RPP memiliki beberapa langkah sederhana seperti penggunaan media belajar daring. Bentuk dari RPP belajar daring yang dibuat sudah disesuaikan dengan belajar tatap muka pada umumnya, yaitu terdiri dari pembukaan, pelaksanaan, dan penutup. Tahapan persiapan tersebut sejalan dengan Rusman bahwa tahapan pelaksanaan pembelajaran terdiri dari kegiatan pendahuluan, inti, dan penutup (Rusman, 2013). Selain itu guru juga mempersiapkan bahan evaluasi seperti soal latihan setelah pemberian materi. Kegiatan tersebut diharapkan mampu membangkitkan semangat siswa untuk mengikuti pembelajaran. Dari dokumentasi yang diperoleh, seperti soal matematika yang diberikan guru berbentuk soal pilihan ganda dan essay.

Bapak Tamimi mempersiapkan bahan ajar yang berbeda antara kelas VIII A dengan VIII D. Seperti contohnya di kelas VIII A hingga kelas VIII C bahan ajar yang diberikan berbentuk video dari youtube, sedangkan untuk kelas VIII D dan VIII E bahan ajar berbentuk foto dan pdf. Berdasarkan pernyataan dari Bapak Tamimi tujuan bahan ajar yang berbeda 
karena menyesuaikan kemampuan siswa yang berbeda juga (Hasil Wawancara dengan Guru Matematika). Pendapat bapak Tamimi sesuai dengan hasil penelitian Mustakim yang memiliki hasil penelitian, bahwa salah satu saran untuk pembelajaran matematika secara daring dengan pemberian soal yang berbeda (bervariatif) yang diberikan pada siswa (Mustakim, 2020). Selain persiapan yang dilakukan guru, siswa juga mempersiapkan diri untuk mengikuti proses pembelajaran daring. Persiapan yang dilakukan siswa memiliki persamaan yaitu mempersiapkan alat tulis, buku, dan kertas folio, meskipun siswa merasa sulit untuk memahami materi. Pernyataan ini berdasarkan hasil wawancara dengan Eva Anisa Kelas VIII C, bahwa persiapan yang dilakukan berupa alat tulis, buku, dan kertas folio untuk menuliskan jawaban setelah itu dikumpulkan ke sekolah. Sama seperti Dimas Nur Kelas VIII B, bahwa kertas folio digunakan untuk menuliskan jawaban dari soal yang diberikan guru dan jawaban tersebut dikumpulkan seminggu sekali di sekolah.

Pembelajaran daring membuat siswa untuk tetap belajar dengan menekankan sikap mandiri. Untuk memulai pembelajaran daring ada siswa yang mempersiapkan materi sebelum pembelajaran dimulai dengan belajar telebih dahulu. Seperti Saskia Diah Nur kelas VIII D yang mempersiapkan materi pembelajaran dengan belajar telebih dahulu. Sedangkan untuk waktu memulai pembelajaran masih ada siswa yang belum bisa tepat waktu dan tetap mengikuti pembelajaran hingga selesai. Keadaan saat pembelajaran daring ini sama seperti penelitian yang dilakukan oleh Asmuni (2020), bahwa keterbatasan guru dalam mengontrol kelas sehingga ada yang tidak mengikuti pembelajaran hingga selesai.

Perbedaan urutan kelas tidak berpengaruh pada semangat siswa dalam mengikuti pembelajaran daring. Siswa yang berada di kelas VIII D maupun VIII E bukan berarti hanya mempersiapkan buku dan alat tulis, seperti hasil wawancara di atas bahwa siswa yang di kelas VIII D melakukan belajar terlebih dahulu sebelum pembelajaran dimulai. Sedangkan untuk siswa yang duduk di kelas VIII B ada juga yang hanya mempersiapkan alat tulis dan buku. Kemudahan belajar daring dirasakan oleh Nisa Hardiyati kelas VIII B yang lebih mudah mempersiapkan mulai pembelajaran untuk tidak membawa buku dan datang ke sekolah. Pembelajaran daring di MTs. Ma'Arif 02 Kotagajah dimulai pukul 08.00, seharusnya siswa tidak terburu-buru mengikuti pembelajaran namun pada nyatanya siswa masih saja telat dan tidak mengikuti pembelajaran hingga selesai

Meskipun pembelajaran matematika dilakukan secara daring, persiapan guru untuk menyampaikan materi tetap disiapkan dengan baik. Seperti langkah proses pembelajaran yang sederhana dan tidak membuat bosan, persiapan bahan ajar yang tidak monoton, serta menentukan media yang tepat dengan kondisi lingkungan belajar. Hal ini sesuai dengan pedoman belajar daring dari Kemendikbud, yaitu tahapan persiapan yang meliputi persiapan guru membuat RPP, menentukan metode atau model, dan menentukan media belajar daring (Surat Edaran Kemendikbud, 2020).

Selain pembelajaran daring, MTs. Ma'Arif 02 Kotagajah melaksanakan pembelajaran secara luring atau tatap muka. Pembelajaran tatap muka hanya berlaku untuk satu hari untuk setiap kelas dalam satu minggu. Dalam persiapan pembelajaran tatap muka, guru hanya mempersiapkan jawaban dari soal yang sebelumnya sudah diberikan pada siswa di WAG. Guru berusaha memilih cara penyelesaian dengan cara yang mudah agar siswa juga mudah untuk memahami jawaban. Kemudian guru membahas jawaban tersebut di depan kelas dan menuliskannya di papan tulis. Sedangkan untuk siswa hanya mempersiapkan alat tulis dan menyalin jawaban guru di buku masing-masing.

Berdasarkan pembahasan yang telah dikaji maka dapat disimpulkan bahwa, perencanaan pembelajaran matematika di MTs. Ma'Arif 02 Kotagajah yang disiapkan guru berupa pembuatan RPP belajar daring, media pembelajaran daring yaitu WAG dan youtube, serta bahan evaluasi dalam bentuk pilihan ganda dan essay. Persiapan guru untuk pembelajaran 
tatap muka seperti pemilihan jawaban yang mudah dipahami siswa, yang kemudian akan dibahas di kelas. Sedangkan persiapan yang dilakukan siswa berbeda-beda seperti mempersiapkan buku, alat tulis, kertas folio, dan beberapa siswa mempersiapkan materi dengan belajar terlebih dahulu. Namun, ada sebagian siswa yang telat mengikuti pembelajaan dan ada juga yang tidak mengikuti pembelajaran hingga selesai.

\section{b. Pelaksanaan Pembelajaran}

Pelaksanaan pembelajaran matematika memiliki perbedaan dalam menggunakan cara penyampaian dan metode. Hal ini dikarenakan adanya karakteristik siswa yang berbeda pada setiap kelas. Menurut bapak Tamimi, kemampuan siswa pada kelas A lebih unggul dibandingkan kelas lainnya, begitu juga dengan kelas B dibandingkan kelas C, D, dan E. Sehingga bapak Tamimi menggunakan cara penyampaian dan metode yang sesuai dengan kemampuan siswa tersebut.

\section{1) Cara Penyampaian Materi}

Berdasarkan hasil wawancara yang telah dilakukan dengan bapak Tamimi selaku guru matematika, bahwa bapak Tamimi menyampaikan materi dengan cara yang mudah agar mempermudah siswa untuk mengikuti pembelajaran daring. Pelaksanaan pembelajaran dilaksanakan menggunakan aplikasi WhatsApp Group (WAG) dan Google Meet, untuk WAG guru menyampaikan materi dalam bentuk foto, pdf, dan video dari youtube. Selain itu, guru juga menjelaskan materi secara tatap muka di kelas pada saat pengumpulan tugas seminggu sekali ke sekolah. Penyampaian materi secara tatap muka diharapkan dapat membantu siswa untuk memahami materi, meskipun dilakukan hanya satu minggu sekali. Tujuan penyampaian materi secara tatap muka ini sejalan dengan Rusman, bahwa salah satu kelebihan pembelajaran tatap muka adanya praktik yang diberikan guru secara langsung pada siswa agar mempermudah siswa memahami materi (Rusman, 2013).

Berdasarkan hasil wawancara dengan siswa, siswa sulit untuk memahami materi sendiri jika guru hanya membagikan link video youtube. Meskipun adanya kesempatan siswa untuk menerima penjelasan guru di hari Rabu dan Kamis dengan waktu yang tidak lama. Pembagian sesi untuk ke sekolah yaitu hari Rabu untuk kelas VIII A hingga VIII C, sedangkan hari kamis untuk kelas VIII D dan VIII E. Menurut siswa pemberian materi dari guru dapat berbentuk pdf dan ditambahkan dengan video dari youtube agar siswa dapat belajar tidak hanya satu sumber.

Kemudian untuk pendapat bapak Tamimi respon yang diberikan siswa hanya sekedar menjawab salam guru dan menjawab perintah guru untuk menyelesaikan soal yang diberikan di WAG. Hal ini dinyatakan oleh Glendy Bagas kelas VIII C bahwa sulitnya memahami materi dan respon yang diberikan hanya menjawab salam guru. Namun berbeda dengan Fikri Ramadhan kelas VIII E yang aktif memberikan umpan balik pada guru, seperti menjawab salam dan perintah guru karena tuntutannya sebagai ketua kelas dan menjadi kebiasaan Fikri.

Cara penyampaian yang dilakukan guru dalam pembelajaran daring akan berpengaruh terhadap pemahaman siswa. Guru seyogyanya mampu memilih cara yang tepat untuk menyampaikan materi. Menurut saran siswa kelas VIII guru hendaknya mampu menyesuaikan cara penyampaian kembali, seperti materi yang bersumber dari youtube tetap dibagikan di WAG namun diberikan penjelasan singkat atau memberikan sesi tanya jawab di WAG. Dengan demikian respon atau umpan balik yang diberikan siswa akan lebih aktif, karena hal tersebut dapat membangkitkan semangat belajar siswa.

Penyampaian guru dalam pelaksanaan pembelajaran akan memiliki kesan tersendiri didiri siswa. Pembelajaran matematika di MTs. Ma'Arif 02 Kotagajah dilaksanakan sesuai 
dengan jadwal yang sudah ditetapkan yaitu hari Selasa dan Jum'at, sedangkan untuk pembelajaran di sekolah dilaksanakan pada hari Rabu dan Kamis sesuai pembagian kelas. Pembelajaran daring dilaksanakan mulai pukul 08.00 hingga selesai. Sedangkan untuk pembelajaran yang dilaksanakan secara tatap muka hanya selama satu jam. Saat pembelajaran berlangsung guru hanya membahas soal latihan sebelumnya yang siswa anggap sulit. Soal yang dibahas berjumlah dua sampai tiga soal. Sedangkan untuk umpan balik siswa saat pembelajaran di kelas hanya memahami jawaban yang dijelaskan oleh guru.

Berdasarkan pembahasan maka dapat disimpulkan bahwa guru menyampaikan materi secara daring melalui media WAG dan youtube. Guru menyampaikan materi dengan bentuk foto, pdf, dan video dari youtube. Selain itu ada penyampaian materi yang dilakukan secara tatap muka di sekolah seminggu sekali. Sedangkan menurut siswa cara guru kurang sesuai jika menggunakan video dari youtube, karena siswa merasa sulit memahami materi secara mandiri. Sedangkan untuk pembelajaran yang di laksanakan di kelas guru menjelaskan jawaban di depan kelas dan siswa menyalin jawaban di buku masing-masing. Untuk umpan balik yang diberikan siswa kurang aktif di WAG, siswa hanya menjawab salam dan perintah dari guru.

\section{2) Metode atau Model Pembelajaran}

Berdasarkan hasil wawancara dengan bapak Tamimi pembelajaran yang dilaksanakan menggunakan metode ceramah dan juga tanya jawab, namun metode tersebut tidak digunakan pada semua materi. Menurut bapak Tamimi materi matematika tetap harus menggunakan metode ceramah meskipun tidak serinci penjelasan saat tatap muka, karena matematika tidak bisa hanya dipahami melalui materi dari foto atau pdf (Wawancara dengan Guru Matematika). Materi matematika yang sering kali tidak bisa siswa pahami secara mandiri memungkinkan untuk menggunakan metode tanya jawab. Karena salah satu kelebihan menggunakan metode tanya jawab untuk membangkitkan siswa dalam mengemukakan pendapat yang sesuai dengan Helmiati (2012), bahwa tujuan penggunaan metode tanya jawab agar pembelajaran tidak berpusat pada guru dan siswa memiliki sikap berani.

Kemudian untuk hasil wawancara dengan siswa kelas VIII, guru tidak menggunakan metode ceramah dan tanya jawab pada semua materi. Guru membagikan materi dengan bentuk pdf, foto, dan juga link video dari youtube. Namun yang menggunakan metode ceramah dan tanya jawab hanya materi pdf dan foto. Sehingga siswa beranggapan bahwa metode tersebut kurang sesuai. Menurut Afrizal Afif kelas VIII B yang mengalami kesulitan memahami materi jika hanya berbentuk video dari youtube. Pendapat lain dirasakan oleh Yusuf kelas VIII A metode kurang sesuai untuk video youtube, tetapi jika video dibuat oleh guru menggunakan bahasa guru sepertinya lebih mudah untuk dipahami.

Meskipun jawaban sudah dijelaskan saat mengumpulkan tugas ke sekolah, sebaiknya guru tetap memberikan penjelasan singkat terkait video yang ada di youtube, kemudian memberikan sesi tanya jawab atau pertanyaan pada siswa sebagai bentuk kepedulian dalam proses pembelajaran. Sedangkan untuk pembelajaran tatap muka yang hanya selama satu jam di kelas selama satu minggu, guru menggunakan metode ceramah untuk menjelaskan jawaban. Untuk metode belajar daring dalam penelitian ini sama seperti penelitian yang dilakukan oleh Mustakim (2020), yang menggunakan beberapa metode yaitu ceramah, diskusi atau tanya jawab, dan penugasan individu.

Metode atau model merupakan cara atau langkah yang ditempuh untuk mengimplementasikan rencana pembelajaran yang sudah dibuat secara optimal. Pemilihan metode yang tepat akan berpengaruh terhadap proses pembelajaran yang dilaksanakan. Guru diharapkan mampu memilih metode yang disesuaikan dengan keadaan dan kondisi siswa, agar proses yang dilakukan dapat mencapai tujuan dari pembelajaran. Sebab keberhasilan 
pencapaian tujuan pembelajaran sangat ditentukan dengan metode, karena materi yang rinci dan berkualitas tidak akan bisa dipahami siswa jika cara penyampaiannya tidak tepat (Sanjaya, 2016).

Berdasarkan pembahasan penelitian maka dapat disimpulkan, bahwa bapak Tamimi menggunakan metode tanya jawab dalam proses pembelajaran matematika. Metode tersebut hanya digunakan jika materi berbentuk foto dan pdf. Sedangkan untuk media youtube guru hanya membagikan link video untuk selanjutnya siswa memahami materi tersebut secara mandiri. Menurut guru pemilihan metode tersebut sudah sesuai karena dipertimbangkan dengan penggunaan kuota internet siswa. Pernyataan bapak Tamimi terkait penggunaan metode sesuai dengan hasil wawancara yang dilakukan dengan siswa. Namun menurut siswa pembelajaran dengan video youtube kurang sesuai, karena siswa merasa kesulitan untuk memahami materi secara mandiri. Sehingga muncul saran dari siswa untuk guru membuat video sendiri atau tetap menggunakan metode ceramah atau tanya jawab meskipun materi bersumber dari youtube.

\section{3) Kendala yang Dialami pada Pembelajaran Daring}

Berdasarkan hasil wawancara yang telah dilakukan terkait kendala yang dialami bapak Tamimi, yaitu kurangnya referensi dalam menggunakan metode belajar. Karena metode belajar yang tidak monoton diharapkan mampu meminimalisir rasa bosan yang dialami siswa. Sedangkan untuk memilih metode belajar harus dipertimbangkan dengan keadaan dan kondisi siswa. Selain itu kendala yang dialami guru saat proses pengoreksian hasil tugas siswa yang hanya melalui WAG (Wawancara dengan Guru Matematika).

Solusi yang diperoleh guru dari pihak sekolah diadakannya satu hari masuk sekolah untuk mengumpulkan tugas, bersamaan dengan itu guru juga dapat menjelaskan materi sebelumnya sehingga siswa mendapatkan penjelasan materi secara langsung. Untuk pengumpulan tugas ke sekolah dibagi beberapa sesi, untuk kelas VIII A hingga VIII C pada hari Rabu sedangkan kelas VIII D dan kelas VIII E pada hari Kamis. Sehingga tugas siswa yang dikerjakan di kertas folio akan mempermudah guru untuk mengoreksi (Wawancara dengan Guru Matematika). Solusi ini sejalan dengan pendapat Agung Prayoga kelas VIII E bahwa pengumpulan tugas ke sekolah seminggu sekali merupakan solusi dari permasalahan yang dialami.

Sedangkan untuk kendala yang dialami siswa selama pembelajaran daring yaitu sulitnya siswa dalam memahami materi, kuota internet yang digunakan untuk proses pembelajaran daring, karena saat materi dari video youtube maka siswa bisa berulang kali menonton video dan tidak semua video dapat dionton secara offline. Tentu saja kendala sinyal yang dialami sebagian siswa juga berpengaruh terhadap pembelajaran. Kendala tersebut sesuai dengan Arifa (2020), bahwa salah satu kekurangan dari pembelajaran daring kuota dan jaringan internet. Meskipun menurut Muhammad Yusuf kelas VIII A bahwa kuota intenet sudah pernah diberikan oleh pihak sekolah, namun hanya satu kali selama pembelajaran daring dilaksanakan.

Kendala atau masalah lainnya dirasakan oleh Intan Anisa kelas VIII A untuk sulitnya memahami materi secara mandiri, bahkan harus mengulang beberapa kali agar dapat memahami materi matematika. Namun untuk kendala memahami materi sudah siswa konsultasikan dengan guru, bapak Tamimi sudah memberikan respon dengan memberikan semangat untuk belajar dan janga putus asa. Seperti yang disampaikan oleh Muhammad Dwi Lutfi kelas VIII D yang telah mengkonsultasikan kendalanya, yaitu kendala tidak bisa berkonsentrasi jika belajar daring dan bapak Tamimi menyarankan untuk belajar lebih giat dan tetap semangat. 
Kendala-kendala yang dialami siswa selama pembelajaran daring juga sama seperti hasil penelitian Handayani \& Irawan (2020), kendala pembelajaran yaitu sinyal internet, kuota internet, dan sulitnya siswa untuk memahami materi. Dan kekurangan belajar daring dalam penelitian Thityn Ayu Nengrum dkk, kekurangan belajar daring dapat membuat beberapa siswa merasa frustasi, cemas, dan bingung saat tidak bisa memahami materi karena pemberian materi yang kurang efektif (Thityn Ayu Nengrum, Najamuddin Peta S. \& Muhammad Nur Iman).

Siswa yang terkadang sulit berkonsentrasi akan memiliki rasa cemas saat penyelesaian soal latihan dan ulangan. Namun sayangnya tidak semua siswa MTs. Ma'Arif 02 Kotagajah yang mengalami kendala selama pembelajaran daring berkenan untuk berkonsultasi dengan guru, padahal guru bisa menjadi tempat siswa untuk berbagi masalah yang dialami selama kegiatan pembelajaran daring. Namun kurang dekatnya siswa dengan guru dapat menjadi penyebab siswa merasa canggung.

Berdasarkan pembahasan yang dilakukan maka dapat disimpulkan, bahwa kendala yang dirasakan guru selama pembelajaran daring saat pengoreksian jawaban dan kurangnya referensi untuk referensi metode belajar. Namun sudah mendapatkan solusi dengan diadakan jadwal masuk sekolah seminggu sekali untuk mengumpulkan tugas, selain itu guru dapat menyampaikan materi secara tatap muka di kelas. Sedangkan kendala yang dialami siswa yaitu sulitnya memahami materi matematika secara daring, borosnya kuota internet, dan beberapa siswa tekendala sinyal. Untuk solusinya pihak sekolah sudah pernah memberikan kuota intenet namun hanya satu kali. Siswa merasa ada kemajuan untuk memahami materi saat penyampaian satu minggu sekali di kelas.

\section{4) Cara Guru Menggunakan Media Pembelajaran}

Berdasarkan hasil wawancara tahapan pelaksanaan, bapak Tamimi menggunakan media WAG dan video youtube untuk pelaksanaan pembelajaran. Bapak Tamimi mengatakan bahwa penggunaan media WAG dan youtube sudah sesuai dengan mempertimbangkan kuota internet siswa, meskipun pada kenyataannya tidak semua materi bisa disampaikan menggunakan WAG (Wawancara dengan Guru Matematika).

Selain WAG dan youtube, bapak Tamimi menyatakan sudah sempat menggunakan media Google Meet sebanyak dua kali untuk di kelas VIII A. Namun, bapak Tamimi masih mempertimbangkan kuota siswa untuk menggunakan media Goggle Meet. Bapak Tamimi mencoba penggunaan media yang baru agar siswa tidak merasa bosan dan tetap semangat mengikuti pembelajaran. Tetapi media tersebut baru digunakan di kelas VIII A, untuk kelas VIII B hingga kelas VIII E guru hanya menggunakan media WAG dan video youtube. Penggunaan media tersebut sejalan dengan penelitian Handayani \& Irawan (2020), bahwa media belajar daring yang digunakan yaitu WhatsApp dan Zoom Meet.

Bapak Tamimi menjelaskan kegiatan pembelajaran daring yang dilakukan menggunakan WAG. Saat pembelajaran akan dimulai guru membuka pembelajaran dengan mengucap salam dan mempersilakan siswa untuk absen. Setelah absen selesai guru membagikan materi dalam bentuk pdf, foto, atau link video dari youtube. Jika materi berbentuk pdf atau foto, guru memberikan metode ceramah kemudian tanya jawab, namun jika materi dari video youtube guru tidak menggunakan metode. Kemudian guru menutup pembelajaran dengan memberikan soal dan salam penutup.

Proses pelaksanaan yang disampaikan oleh bapak Tamimi sesuai dengan menurut Glendy Bagas kelas VIII C dan Fikri Ramadhan krlas VIII E yaitu guru memulai pembelajaran dengan mengucap salam, kemudian guru memberikan waktu pada siswa untuk absen. Setelah absen guru memberikan materi di WAG dalam bentuk pdf atau video youtube. Untuk pdf guru memberikan penjelasan dan sesi tanya jawab, namun untuk materi dari media youtube guru 
tidak menjelaskan kembali dan langsung memberikan soal latihan. Dan guru menutup pembelajaran dengan mengucap salam di WAG.

Namun menurut Muhammad Yusuf kelas VIII A bapak Tamimi melaksanakan pembelajaran menggunakan media WAG, youtube, dan Google Meet. Untuk materi yang diberikan oleh bapak Tamimi hanya melalui video youtube, dengan pembukaan guru mengucap salam kadang juga menyapa siswa. Dan untuk tahap terakhir guru memberikan soal serta menutup pembelajaran dengan mengucap salam. Pernyataan dari Nisa Hardiyanti kelas VIII B bahwa media yang digunakan sudah sesuai untuk di era pandemi, tetapi jika bapak Tamimi menggunakan media Google Meet selain di kelas VIII A akan lebih baik lagi. Media pembelajaran yang dipilih guru hendaknya disesuaikan dengan kondisi siswa. Metode dan bentuk bahan ajar yang berbeda akan meminimalisir rasa bosan siswa. Meskipun media belajar daring yang sering digunkan adalah WAG, maka hendaknya guru membuat langkahh pembelajaran yang lebih menarik. Sehingga pembelajaran yang telah dilaksanakan mampu mencapai tujuan pembelajaran matematika.

Dapat disimpulkan bahwa bapak Tamimi sudah menggunakan media WAG, youtube, dan google meet di kelas VIII MTs. Ma'Arif 02 Kotagajah. Tetapi untuk media google meet baru digunakan dua kali dan hanya di kelas VIII A, alasan guru karena mempertimbangkan kuota internet. Tujuan dari penggunaan media yang baru agar media tidak monoton dan siswa tidak merasa bosan saat pembelajaran. menurut beberapa siswa guru menggunakan media dengan mengucap salam sebagai pembuka pembelajaran, kemudian guru memberikan waktu siswa untuk menuliskan nama di WAG sebagai bentuk absen. Setelah itu guru memberikan materi yang berbentuk foto, pdf,atau video youtube. Guru menggunakan metode ceramah dan tanya jawab untuk materi berbentuk foto dan pdf, sedangkan hanya membagikan link video jiak bersumber dari youtube. Proses pembelajaran matematika secara daring mempersulit siswa untuk memahami materi, terlebih untuk materi yang hanya dari youtube.

c. Evaluasi Pembelajaran

Berdasarkan hasil wawancara dengan bapak Tamimi, proses evaluasi yang diberikan dengan memberikan soal ulangan akhir semester dan ulangan tengah semester seperti sekolah lain pada umumnya. Untuk setiap pertemuan guru memberikan soal latihan pada siswa yang dikumpulkan seminggu sekali ke sekolah, yaitu pada hari Rabu dan Kamis. Soal-soal tersebut diberikan guru dalam bentuk foto yang dibagikan di WAG. Soal latihan berbentuk pilihan ganda dan essay, terkadang juga guru memberikan soal yang sudah ada di internet dengan mengirimkan link di WAG kemudian dikerjakan oleh siswa. Kemudian Bapak Tamimi menyatakan bahwa hasil belajar siswa selama belajar daring mengalami penurunan. Sehingga guru matematika mencoba untuk menggunakan GoogleMeet dalam penyampaian materi yang baru diuji cobakan di kelas VIII A. Melakukan penggunaan media yang baru diharapkan mampu meningkatkan pemahaman siswa terhadap materi matematika (Wanwancara dengan Guru Matematika).

Pemahaman siswa terkait materi matematika akan berdampak pada hasil belajar. Salah satu kendala yang siswa alami selama belajar daring yaitu sulitnya memahami materi, karena siswa harus memahami materi secara mandiri. Menurut bapak Tamimi hasil belajar siswa kelas VIII di MTs. Ma'Arif 02 Kotagajah mengalami penurunan dari proses sebelum ke sesudah belajar daring, meskipun pembelajaran matematika menggunakan pembelajaran luring dengan siswa datang ke sekolah satu minggu sekali.

Berdasarkan hasil rekapitulasi nilai di kelas VIII A memiliki rata-rata nilai ulangan semester sebelum belajar daring sebesar 87 , namun setelah adanya belajar daring mengalami penurunan menjadi 75,3. Kemudian di kelas VIII B yang rata-rata nilai ulangan akhir semester 
awalnya 86 menjadi 75 . Untuk kelas VIII C semula nilai rata-rata ulangan akhir semester 84,2 namun setelah belajar daring menjadi 75,1 . Kelas VIII D rata-rata nilai ulangan akhir semester sebelum belajar daring 82,5 menurun menjadi 73,7. Dan untuk kelas VIII E rata-rata nilai yang semula 80,2 namun setelah pembelajaran daring menurun menjadi 72,6.

Pembelajaran secara daring tentunya akan mempersulit guru maupun siswa dalam pelaksanaan pembelajaran. Sehingga saran dari guru maupun siswa perlu diperhatikan untuk proses pembelajaran yang lebih baik. Saran dari bapak Tamimi untuk sesama guru matematika seperti pemilihan model atau metode belajar daring benar-benar dipertimbangkan dengan keadaan siswa, baik kebiasaan dalam memahami materi, sinyal internet siswa, dan banyak kuota yang digunakan.

Evaluasi pembelajaran merupakan tahapan penting untuk melihat dan menilai sejauh mana proses pembelajaran yang telah dilakukan, sudah sesuai atau belum metode yang digunakan, cara penyampaian yang lakukan, hingga sejauh mana pemahaman siswa tentang materi yang sudah tersampaikan. Hal ini sesuai denga Sanjaya (2016), bahwa evaluasi merupakan aspek yang berguna untuk mengukur dan menilai keberhasilan belajar siswa, selain itu evaluasi berfungsi sebagai umpan balik yang bermanfaat untuk guru karena kinerja dan cara pengelolaan pembelajaran. Evaluasi pembelajaran hendaknya dilakukan baik secara pribadi maupun berdiskusi dengan sesama guru.

Kemudian saran-saran yang diberikan siswa untuk guru matematika, seperti Intan Anisa Putri kelas VIII A yang memberikan saran untuk guru matematika memberikan sesi tanya jawab yang lebih banyak. Kemudian dari Syifa Annisatun Nabilla kelas VIII C untuk adanya penambahan waktu pemberian materi matematika di sekolah saat pengumpulan tugas. Saran yang hampir sama disampaikan oleh Dimas Nur kelas VIII B, bahwa guru seharusnya memberikan penjelasan kembali atau menanyakan pada siswa terkait materi dalam bentuk video youtube. Fikri Ramadan kelas VIII E juga menyarankan agar guru membuat video sendiri dan memberikan rumus cepat matematika pada siswa. Saran-saran untuk perbaikan pembelajaran matematika kedepannya sesuai dengan hasil penelitian yang dilakukan oleh Mustakim (2020), bahwa pemilihan adanya penjelasan materi sebelum pemberian soal, meminimalisir pemberian materi melalui video dengan kuota besar, pemberian materi matematika yang lebih singkat, dan pembelajaran yang menggunakan video call seperti Google meet.

Seorang guru seharusnya mampu menumbuhkan dan membangkitkan semangat belajar siswa serta memberikan motivasi atau menyapa siswa. Guru mampu memahami karakter dan kemampuan siswa yang berbeda-beda, sehingga guru dapat memberikan perlakuan yang tepat pada siswa atau perlakuan pada setiap kelas. Selain memberikan perlakuan yang tepat, guru harus menciptakan komunikasi dengan siswa yang lebih luwes. Dengan hubungan yang baik antara guru dan siswa akan memudahkan guru mentransfer ilmu pada saat pembelajaran berlangsung. Dengan demikian, semakin baik pembinaan komunikasi dan hubungan yang dilakukan maka respon yang muncul akan semakin baik pula. Selain respon baik yang muncul diharapkan juga adanya kemajuan terhadap keberhasilan belajar siswa.

\section{Simpulan}

Berdasarkan hasil penelitian yang telah dilakukan maka dapat disimpulkan bahwa pembelajaran matematika meiputi 3 tahapan yaitu: persiapan pembeajaran, pelaksanaan pembelajaran, dan evaluasi pembelajaran selama daring. Persiapan pembelajaran yang dilakukan guru seperti RPP, bahan ajar, dan evaluasi belajar sudah mengikuti keadaan 
pembelajaran daring. RPP yang dibuat guru dengan media belajar daring dan langkah yang sederhana. Guru membagikan bahan ajar sebagai materi di WhatsApp Group (WAG).

Pelaksanaan pembelajaran matematika yang telah dilakukan di MTs. Ma'Arif 02 Kotagajah dengan metode, cara penyampaian materi, dan media yang digunakan kurang sesuai dengan keadaan siswa. Untuk media pembelajaran yang digunakan oleh guru melalui WAG dan video dari youtube, namun sudah dua kali menggunakan GoogleMeet di kelas VIII A. Pembelajaran dilakukan secara luring satu minggu sekali dengan tujuan siswa mengumpulkan jawaban soal, dengan waktu untuk belajar luring hanya dibatasi selama satu jam.. Pelaksanaan belajar luring hanya sebatas guru menjelaskan cara penyelesaian soal dan siswa menyalin jawaban di buku masing-masing. Kendala yang dialami siswa yaitu sulit dalam memahami materi pembelajaran.

Evaluasi dari pembelajaran daring yang telah terlaksana berjalan dengan baik sesuai pedoman RPP melalui WAG, namun hasil belajar siswa menurun dikarenakan siswa sulit untuk memahami materi. Meskipun guru sudah memberikan penjelasan ulang saat pengumpulan tugas seminggu sekali, namun pemahaman siswa belum bisa seperti sediakala saat pembelajaran tatap muka. Guru menjadikan jawaban yang dikerjakan siswa sebagai bahan evaluasi, dengan soal diberikan saat pembelajaran dari melalui WAG.

\section{Konflik Kepentingan}

Penulis menyatakan tidak ada konflik kepentingan

\section{Referensi}

Arifa, F. N. (2020). Tantangan Pelaksanaan Kebijakan Belajar Dari Rumah Dalam Masa Darurat Covid-19. Info Singkat; Kajian Singkat Terhadap Isu Aktual Dan Strategis, XII (7/I), 6.

Asmuni. (2020). Problematika Pembelajaran Daring di Masa Pandemi Covid-19 dan Solusi Pemecahannya. Jurnal Pedagogy: Jurnal Penelitian dan Pengembangan Pendidikan, 7(4).

Handayani, S. D., \& Irawan, A. (2020). Pembelajaran matematika di masa pandemic covid-19 berdasarkan pendekatan matematika realistik. Jurnal Math Educator Nusantara: Wahana Publikasi Karya Tulis Ilmiah di Bidang Pendidikan Matematika, 6(2), 179189.

Naila, R. J. (2021). Pembelajaran Matematika Semester Ganjil Selama Pandemi Covid-19 Di Mts Al-Hidayah Purwokerto Utara (Doctoral dissertation, IAIN Purwokerto).

Helmiati. (2012). Model Pembelajaran. Yogyakarta: Aswaja Pressindo.

Kementerian Pendidikan dan Kebudayaan Republik Indonesia, Surat Edaran Nomor 4 Tahun 2020 tentang Pelaksanaan Kebijakan Pendidikan dalam Masa Darurat Penyebaran Coronavirus Disease (COVID 19). Poin 2a-2c. 
Mustakim. (2002). Efektivitas Pembelajaran Daring Menggunakan Media Online Selama Pamdemi COVID-19 pada Mata Pelajaran Matematika. Al-Asma: Journal of Islamic Education, 2 (1).

Nengrum, Thityn Ayu, Najamuddin Peta Solong, dan Muhammad Nur Iman. (2002). Kelebihan dan Kekurangan Pembelajaran Daring dalam Pencapaian Kompetensi Dasar Kurikulum Bahasa Arab di Madrasah Ibtidaiyah2 Kabupaten Gorontalo. Jurnal Pendidikan, 30(1)

Pujiadi. (2016). Direktorat Jenderal Guru dan Tenaga Kependidikan Kementerian Pendidikan dan Kebudayaan. Kurikulum Matematika 2 dan Pemanfaatan Media Pembelajaran.

Rusman.(2016). Model-Model Pembelajaran Mengembangkan Profesionalisme Guru. Cet. Ke6. Jakarta: Rajagrafindo Persada.

Sanjaya, Wira. (2016). Strategi Pembelajaran Berorientasi Standar Proses Pendidikan. Cet. Ke-12. Jakarta: Prenadamedia Group.

Sholihah, D. A., \& Mahmudi, A. (2015). Keefektifan experiential learning pembelajaran matematika MTs materi bangun ruang sisi datar. Jurnal riset pendidikan matematika, 2(2), 175-185.

Sugiyono. (2010). Metode Penelitian Kuantitatif Kualitatif dan R\&D. Cet. Ke-11. Bandung: Alfabeta.

Syahlan. (2015). Literasi Matematika dalam Kurikulum 2013. Keguruan: Jurnal Penelitian, Pemikiran, dan Pengabdian, 